\title{
Tutkija ja tiede suomalaisessa yhteiskunnassa vuonna 2020
}

Vuosina 2013, 2016 ja 2019 julkaistujen tiedebarometrien löydösten mukaan suomalaisten luottamus tieteeseen on vankkaa. Kansalaisten tiedevastaisuudesta ei voi puhua, jos vuoden 2019 raportissa (Tiedebarometri 2019) seitsemän kymmenestä vastaajasta ilmoittaa seuraavansa tiedettä laajasti, niin luonnon, yhteiskunnan kuin taloudenkin osalta. On kuitenkin huomattava, että Tiedebarometri liikkuu abstraktilla tasolla: Vuoden 2019 raportin johdannossa todetaan, että "tekstissä ei määritellä mitä tiede on tai mikä on tai ei ole tiedettä". Näin ollen vastauksissa on tiettyä tulkinnallisuutta siitä, millainen mielikuva vastaajalla on "tieteestä".

Tiedebarometrissa todettiin myös, että tiedepolitiikka kiinnosti vähiten, mikä saattaa vaikuttaa siihen, että tiedettä arvostavat tuntevat kuitenkin kovin vähän tieteen sisäisiä mekanismeja (Tiedebarometri 2019, 13). Vaikka tämä on tiedeyhteisön kannalta olennainen näkökulma, se jää ymmärrettävästi vieraaksi suurelle yleisölle.

Etenkin yhteiskuntatieteellinen tutkimus vaikuttaa tulevan entistä herkemmin haastetuksi julkisuudessa. Haasteet eivät välttämättä niinkään liity siis tieteeseen sinänsä, vaan tiettyihin tieteenaloihin tai tutkijoihin - jopa tutkimusmetodeihin. Anu Kantolan ja Hanna Kuuselan kirja Huipputuloiset (2019) nostatti voimakasta keskustelua nimenomaan laadullisiin tutkimusmenetelmiin ja laadulliseen tutkimiseen liittyen (Mikko Räkköläinen arvostelee kyseisen teoksen tässä Politiikka-lehden numerossa). On myös huomattavaa, että edellä mainittua, yhteiskuntatieteiden metodologisiin lähtökohtiin kiinnittyvää kriittistä keskustelua käytiin korostuneesti perinteisessä ja sosiaalisessa mediassa sen sijaan, että teema olisi noussut vastaavalla tavalla esiin tieteen omilla foorumeilla. Kritiikki vaikuttikin kohdistuvan vähemmän tutkimuksen substanssiin, ja enemmän tutkijoiden ammattitaitoon sekä käsityksiin näiden riippumattomuudesta suhteessa tutkimusprosessin aikana tehtäviin valintoihin.

Jälkimmäisessä lienee kyse pikemminkin kommentoijien omasta tiedekäsityksestä. Koska tieteellinen keskustelu käytiin julkisella foorumilla (ks. esim. Määttänen 2019), dosentti Hanna Ylöstalo (2019) teki yleistajuisen tiedeteon avaamalla Twitterissä mitä laadullinen tutkimus oikein pitää sisällään. Käydystä keskustelusta voimme kenties päätellä, että vaikka tieteen arvostus on erilaisten kyselytulosten perusteella ilmeisen korkealla, tutkijoiden täytyy olla entistä valmiimpia puolustamaan työtään myös julkisessa keskustelussa tiedeyhteisön ulkopuolisen yleisön kanssa.

Vastaavasti heti alkuvuodesta 2020, etenkin perussuomalaiset poliitikot kritisoivat akatemiatutkija ja historioitsija Oula Silvennoisen saamaa rahoitusta Suomen Akatemialta (Hartikainen 2020). Kantaa ottava tutkija tuntui tässä tilanteessa rikkovan odotuksia neutraalista ja objektiivisen etäisyyden tutkimuskohteeseensa säilyttävästä tutkijasta. Tai ehkä ongelma olikin se, että Silvennoisen Suomen sotahistoriaa käsittelevät tutkimusaiheet (ks. esim. Silvennoinen 2017) ärsyttivät (Penttilä 2020). Tutkijoilla on kuitenkin oikeus osallistua julkiseen keskusteluun myös kansalaisina. Silvennoinen on myös kirjoittanut saamastaan palautteesta, jonka taustalla hän näkee todennäköisemmin tutkimukseensa liittyvän uutisoinnin kuin itse tutkimuksen (Silvennoinen 2019). 
Silvennoisen tapauksen ympärille kietoutui myös poliittiselta kentältä kantautunutta kritiikkiä tieteellisen tutkimuksen rahoitusmekanismeihin liittyen (ks. esim. Hartikainen 2020). Useampi nykyinen ja entinen perussuomalaisten kansanedustaja moitti edellä mainitussa keskustelussa myös Suomen Akatemian päätöstä myöntää rahoitusta Silvennoisen tutkimushankkeelle "Suomi ja lopullinen ratkaisu". Vaikka nämä kriittiset huomiot olivatkin selvästi yhden tutkijan persoonaan henkilöityneitä, kävi niistä samalla ilmi, ettei kaikkien poliitikkojen ymmärrys tieteen rahoituksen myöntöperusteista sekä esimerkiksi hankehakemusten vertaisarviointikäytännöistä ole välttämättä vankalla pohjalla.

Tieteen rahoitukseen liittyvien sääntöjen ja mekanismien tunteminen olisi voinut kanavoida esiin myös rakentavampaa, suomalaisen tieteen rahanjakomallien rakenteisiin kiinnittyvää kriittistä tarkastelua. Näihin kysymyksiin liittyenhän on myös käyty viime vuosina vilkasta tiedepoliittista keskustelua (ks. esim. Honkonen 2016). Yhtä kaikki, tiedepoliittisen keskustelun henkilöitymisen orastava trendi nostaa esiin vakavan kysymyksen: onko tutkijalla velvollisuus osallistua keskusteluun, jonka lähtökohdat ovat ilmeisen vastakkainasettelua lietsovat (ks. Politiikasta.fi 2019)? Kysymys on sitäkin painokkaampi, kun huomioidaan tutkijoiden urapolkuihin vaikuttavat moninaiset vaatimukset kansainvälisestä huippututkimuksesta kasvatustehtävän kautta yhteiskunnallisten vuorovaikutustilanteiden hallintaan (Haukkala 2019).

\section{AVOIMEN JULKAISEMISEN LUPAUS JA HAASTEET}

Yritysmaailmasta peräisin oleva ilmaisu "ainoastaan muutos on pysyvää" on tullut tutuksi myös suomalaisissa yliopistoissa ja tieteen kentällä laajemmin. Keskustelut tutkijuuden muutoksesta (ks. esim. Peltonen ym. 2019) tuntuvat arkipäiväisiltä osin juuri siksi, että ne käsittelevät arkeamme. Politiikka-lehtikin on pääkirjoituksissaan käsitellyt suomalaisen tiedekentän muutosta (Lahtinen, Poutanen ja Juntunen 2019a; 2019b). On tärkeää pysähtyä hetkeksi tarkkailemaan muutoksen seurauksia.

Politiikka-lehden kohdalla tiedekentän muutos on tarkoittanut avoimen digitaalisen julkaisutoiminnan jatkamista toiseen vuoteen. Vaikka vuoden päätteeksi jatkossakin julkaistaan Politiikka-lehden vuosikirja (jos omasi jäi vuodelta 2019 saamatta, sen voi tilata Valtiotieteelliseltä yhdistykseltä) myös fyysisessä muodossa, säännöllinen julkaisutoiminta on siirtynyt verkkoon. Moni muu tiedelehti on tämän siirroksen jo tehnyt, toisilla se on ehkä vielä edessä. Perinteisen tiedejulkaisun kentän muutos on kuitenkin ajautunut eräänlaiseen niukkuuden välitilaan, jossa lehdet pyrkivät uudistumaan, mutta resursointi ei ole merkittävästi parantunut. Esimerkiksi avoimeen julkaisemiseen siirtymisen vaikutusta tieteellisten yhdistysten talouteen ei ole vielä luotettavasti voitu mitata.

Avoin julkaiseminen on ehdottomasti kannatettavaa, mutta sitä voidaan kehittää vain julkaisijoiden resurssien ja tieteellisten yhdistysten toimintalogiikan puitteissa. OKM:n rahoituksen ehtona on, että tiedelehti siirtyy avoimeen julkaisemiseen, mutta tätä ei ole vielä huomioitu konkreettisesti tiedelehtien taloudellisen perustan turvaamisen osalta. Myös tiedejulkaiseminen on arvostetusta tehtävästään huolimatta vakavien, jopa perustavanlaatuisten kysymysten edessä. Tieteen avoimuus ja tutkimuksen vaikuttavuus nousevat usein esille poliitikkojen 
puheissa, ministeriöiden linjauksissa ja yliopistojen strategioissa, mutta puheiden tueksi tarvitaan pian myös aitoja tekoja.

Suomenkielisen tutkimustiedon julkaisu on juuri tieteellisten yhdistysten ja seurojen - kuten Valtiotieteellisen yhdistyksen - varassa. Suomeksi julkaiseminen on ohittamattoman tärkeää myös julkisen keskustelun ja tietopohjaisen päätöksenteon kannalta. Näin erityisesti aikakautena, jolloin tutkimustiedon merkitystä entistä herkemmin kyseenalaistetaan yhteiskunnallisessa keskustelussa yllä kuvatuin tavoin.

Tiedejulkaiseminen vaatii tuekseen ennakoitavuutta, suunnitelmallisuutta ja pitkäjänteisyyttä. Vastaavia suunnitelmia avoimen tieteen hyödyntämiseksi on laadittu ennenkin (OKM 2014), mutta niiden toimivuus on jäänyt kyseenalaiseksi. Useissa puolueissa puhuttiin vaalikeväänä 2019 koulutuksen arvon tai kunnian palautuksesta. Sanna Marinin hallitus on ottanut avoimen tieteen osaksi hallitusohjelmaansa (Valtioneuvosto 2019), mikä antaa toiveita siitä, että tiedejulkaisemiseen voisi tulla myönteisiä muutoksia. Hallitus korostaa tietopohjaista politiikkaa ja yhteistyötä tiedeyhteisön kanssa sekä esittää, että tutkimustyön arvioinnissa painotettaisiin enemmän yhteiskunnallista vaikuttamista.

\section{TIEDOLLA JOHTAMISEN KAKSITERÄINEN MIEKKA}

Tiedolla johtaminen ei ole täysin ongelmatonta. Toisinaan tieteeseen ja tietoon kytketään voimakkaan positivistisia oletuksia, mikä on omiaan luomaan keinotekoista rajaa tieteen ja sen yhteiskunnallisuuden välille. Varsinkin yhteiskuntatieteissä on kuitenkin myös emansipatorisia ja kriittisiä tutkimusperinteitä. Tekninen tiedonintressi puolestaan palvelee helposti teknokraattista hallintaa. Antti Ronkainen (2019) esittää, että

[t]ietopohjaisen politiikan seurauksena poliittista vastuuta annetaan enemmän asiantuntijoille. Hyvinkin epävarman asiantuntijatiedon perusteella määritellään hallituksen politiikan reunaehtoja. Seurauksena on hieman nurinkurisesti päätöksenteon jäykistyminen ja muuttuminen entistä sekavammaksi, kun asiantuntijoilla ei ole tarjota yksiselitteisiä [tietoja].

Tiedolla johtamisesta puhuttaessa on myös syytä muistaa, että asiantuntijatietoon ja sen soveltamiseen voi epävarmuuksien ja häiriöiden keskellä liittyä myös mittavia yhteiskunnallisia ja inhimillisiä panoksia. Tätä kirjoittaessa edelleen maailmaa ravisutteleva Covid-19 pandemia on osoittanut, paitsi asiantuntijatiedon väistämättömän vajavaisuuden suhteessa poikkeusoloissa tehtyyn poliittiseen päätöksentekoon, myös merkittäviä kansallisia eroja sen suhteen, kuinka valmiita asiantuntijatiedon pohjalta ylipäätään ollaan tekemään kipeitä tilannesidonnaisia päätöksiä ja ennakointia (ks. esim. Aaltola 2020, 6).

Asiantuntijatiedon hyödyntämiseen liittyvien poliittisten kertoimien kasvu on joka tapauksessa normaaliolosuhteissakin näkyvä kansainvälinen trendi. Hanna Ylöstalo (2020) kuvaa asiantuntijatiedon kasvavaa merkitystä jopa varjohallinnaksi. Kyse ei niinkään ole tutkijoiden valtapyrkimyksistä, vaan siitä kuinka tieteellistä tutkimusta voidaan käyttää poliittisten päätösten suojaverhona. Parhaimmillaan tietopohjainen päätöksenteko haastaa arkisia uskomuksia, sekä lisää poliittisten vaikutusten läpinäkyvyyttä. Kuitenkin Ylöstaloa lainaten: 
Tieto ei kuitenkaan tarjoa valmiita ratkaisuja, vaan muutoksen suunnan määrittää viime kädessä hallitusvastuussa olevien poliittisten puolueiden arvot ja ideologia. Niitä tulee perustella kansalaisille muin argumentein kuin sillä, että ne ovat tieteellisesti oikein tai totta.

Tutkijaa varmasti ilahduttaa, että hänen työnsä hedelmät kiinnostavat päättäjiä ja suurta yleisöä. Tietopohjainen päätöksenteko voi kuitenkin pahimmillaan johtaa myös demokraattisen tilan kaventumiseen, ja poliittisten valintojen lukitsemiseen paikalleen. Kenties juuri "totuudenjälkeisyys" (Hyvönen 2019) ajaa poliitikkoja kovaa vauhtia kohti tietoperusteisuutta myös alueilla, joilla tutkittu tieto ei voi antaa realistisesti suoria politiikkasuosituksia, ei ainakaan niin nopeasti kuin poliitikot haluaisivat.

Tässä lehdessä julkaistaan kaksi vertaisarvioitua artikkelia. Näistä ensimmäinen on Rasmus Mannerströmin, Joona Muotkan, Sointu Leikaksen ja Jan-Erik Lönnqvistin poliittisia asenneprofiileja kartoittava tutkimus. Tutkimus tarkastelee ihmisten omaksumia asennekokonaisuuksia - siis poliittisia ideologioita - joita sosiaaliset ryhmät ylläpitävät. Monet näistä kokonaisuuksista liittävät yhteen monipuolisia asenteita, joista tutkimukseen valittiin asenteet maahanmuuttoa, sosiaalietuuksia, tuloeroja, ympäristön huomioimista ja puolustusvoimien vahvuutta kohtaan. Artikkelissa muodostetaan neljä asenneprofiilia: (1) vasemmistoliberaalit, (2) oikeistoliberaalit, (3) vasemmistokonservatiivit ja (4) oikeistokonservatiivit. Artikkelien löydösten mukaan parhaiten toimeentulevat, terveimmät ja koulutustasoltaan keskiarvoa lähellä olevat suhtautuivat odotusten vastaisesti kaikkein kielteisimmin maahanmuuttoon. Tulokset tukevat viimeaikaisia havaintoja sosiokulttuuristen kysymysten kasvavasta merkityksestä ja osoittavat kuinka oleellista nykyisessä poliittisessa ilmapiirissä on huomioida eri ideologisten ulottuvuuksien risteymiä.

Numeron toinen vertaisarvioitu Anna Elomäen, Armi Mustosmäen ja Paula Koskinen Sandbergin artikkeli käsittelee Sipilän hallituksen (2015-2019) elokuussa 2017 aloittamaa ja helmikuussa 2018 kuoppaamaa perhevapaauudistusta päätöksenteon prosessien ja vallan näkökulmasta. Artikkeli selvittää, miksi perhevapaajärjestelmän uudistukset ovat osoittautuneet niin vaikeiksi. Epäonnistuneet prosessit ovat erityisen kiinnostavia, sillä ne kertovat paljon toimijoiden välisestä dynamiikasta ja valtasuhteista. Uudistuksen kipukohdat liittyvät niin poliittisten puolueiden ideologisiin eroihin kuin uudistusten vesittymiseen kolmikantaisessa politiikkaprosessissa, jossa työmarkkinakeskusjärjestöt osallistuvat politiikan muotoiluun. Artikkeli perustuu laajan asiakirja-aineiston sekä uudistukseen osallistuneiden toimijoiden haastatteluiden laadulliseen tutkimukseen.

Numerossa 1/2020 julkaistaan myös kaksi keskustelua-artikkelia. Professori Molly Andrewsin kirjoittama ja Irinja Bickertin kääntämä artikkeli poliittisesta anteeksiannosta perehtyy entisen ItäSaksan salaisen poliisin STASIn tarkkailun ja häirinnän kohteeksi joutuneiden tuntemuksiin, ja näkökulmiin sekä anteeksiannon politiikkaan. Aihetta lähestytään narratiivisesta näkökulmasta. 
Numeron toinen keskustelua-artikkeli pohjaa VTT Ilkka Kärrylän väitöstilaisuudessaan Helsingin yliopistossa 30.11.2019 pitämään lektioon. Kärrylä käsittelee poliittisen talouden muotoutumista 1960-luvulta 1990-luvulle Suomessa ja Ruotsissa. Keskeinen jännitys rakentuu "taloudellisen demokratian" käsitteen ympärille. Perinteiselle vasemmistolle käsite tarkoitti julkista talouden suunnittelua ja ohjailua, sekä työntekijöiden valtaa työpaikoilla. Oikeiston puheessa taasen taloudellinen demokratia viittasi yksityisomistajuuden laajentamiseen sekä yhteistoimintaan työpaikoilla. Näiden näkökulmien muuttuminen ideologisten tulkintojen mukaan sisälsi myös vallitsevien uskomuksien muutoksen. Kärrylä katsoo, että etenkin globaalien haasteiden myötä taloudesta on tullut poliittista, vaikka taloudellisen demokratian käsite onkin ajautunut marginaaliin.

Numeron 1/2020 sisältöä täydentää kolme kirja-arviota. Mikko Räkköläinen arvioi paljon keskustelua herättäneen Anu Koivusen ja Hanna Kuuselan teoksen Huipputuloiset (2019: Vastapaino). Räkköläinen toteaa arviossaan, että teoksen perimmäinen vahvuus on sen tavassa tuoda esiin syviä normatiivisia näkemyksiä, joille sen tutkiman, monin tavoin vaikutusvaltaisen ryhmän yhteiskunnalliset käsitykset perustuvat. Tero Toivanen arvioi puolestaan Antti Kujalan teoksen Kivenmurskaajat. Kolonialismin historia (2019: Atena Kustannus). Toivanen katsoo, että kansainvälisen poliittisen talouden historian kattava suomenkielinen esitys on jo itsessään merkkiteko. Viimeisenä vaan ei vähäisempänä kirja-arviona Aleksi Lohtaja käsittelee Keir Milburning teosta Generation Left (2019: Polity), joka nostaa sukupolviulottuvuutta vahvemmin poliittisen keskustelun keskiöön. Lohtajan mukaan teos onnistuukin tuomaan nykyistä poliittista tilannetta lähestyvien (talouskriisi, ilmastomuutos) sukupolvien välisen eron aiempaa korostetummin esiin. Poliittisilla päätöksillä on näin väistämättä erilaista korostunutta merkitystä eri sukupolville.

Vuoden 2020 ensimmäinen Politiikka-lehden numero on omistettu professori Olavi Borgin (1935-2020) muistolle, jota kunnioitamme julkaisemalla Tapio Raunion ja Ilkka Ruostetsaaren laatiman muistokirjoituksen.

\section{MIKKO POUTANEN, TAPIO JUNTUNEN JA MIKKO LAHTINEN}

\section{LÄHTEET}

Aaltola, Mika. 2020. Covid-19 - A Trigger for Global Transformation? Political Distancing, Global Decoupling and Growing Distrust in Health Governance. FIIA Working Paper 113. Helsinki: Finnish Institute for International Affairs. Saatavilla https://www.fiia.fi/wp-content/uploads/2020/03/wp113 covid-19_a-trigger-for-global-transformation.pdf. Viitattu 30.3.2020.

Hartikainen, Jarno. 2020. "Perussuomalaiset moittivat Suomen Akatemian päätöstä rahoittaa holokaustitutkimusta - näin Akatemia kommentoi." Helsingin Sanomat, 10.1.2020. https://www.hs.fi/politiikka/ art-2000006368202.html. Viitattu 20.3.2020.

Haukkala, Hiski. 2019. Täydellinen tutkija? Turbulentin maailman ja kansainvälisen politiikan välisestä suhteesta. Politiikka 61(1), 75-80. 
Honkonen, Juha. 2016. " Tutkimus ryöpyttää Suomen Akatemiaa: Tehottomuutta, suosimista, avoimuuden puutetta." Helsingin Sanomat, 10.4.2016. https://www.hs.fi/sunnuntai/art-2000002895392. html. Viitattu 30.3.2020.

Hyvönen, Ari-Elmeri. 2019. Antto Vihma, Jarno Hartikainen, Hannu-Pekka Ikäheimo ja Olli Seuri, Totuuden jälkeen. Miten media selviää algoritmien ja paskapuheen aikana. Politiikka 61(2), 167-173.

Koivunen, Anu ja Kuusela, Hanna. 2019. Huipputuloiset. Tampere: Vastapaino.

Määttänen, Juuso. 2019. ”Tutkittiinko rikkaiden ajatuksia oikein? Tutkimus huipputuloisista aiheutti arvosteluryöpyn, näin tutkimusmenetelmien asiantuntija arvioi.” Helsingin Sanomat, 5.9.2019. https://https://www.hs.fi/kulttuuri/art-2000006228558.htm. Viitattu 20.3.2020.

Opetus- ja kulttuuriministeriö 2014. Tutkimuksen avoimuudella yllättäviä löytöjä ja luovaa oivaltamista: Avoimen tieteen ja tutkimuksen tiekartta 2014-2017. Opetus- ja kulttuuriministeriön julkaisuja 2014:20.

Peltonen, Hannes, Pennanen, Henna-Riikka, Haukkala, Hiski, Poutanen, Mikko ja Tennberg, Monika. 2019. Politiikasta-raati: Tutkijuus muutoksessa. Politiikasta, 21.3.2019. https://politiikasta.fi/politiikasta-raati-tutkijuus-muutoksessa/. Viitattu 26.6.2019.

Penttilä, Pauliina. 2020. "Äärioikeisto kusitolppa." Suomen Kuvalehti, 31.3.2020. https://suomenkuvalehti. fi/jutut/kotimaa/han/oula-silvennoinen-vaittelee-perussuomalaisten-kanssa-eika-pelkaa-puoluejasenyyden-leimaavan-osallistuminen-on-kansalaishyve/. Viitattu 22.3.2020.

Politiikasta. 2019. Juttusarja: Kun tutkija kohtaa vihaa. https://politiikasta.fi/tag/kun-tutkija-kohtaa-vihaa/. Viitattu 23.3.2020.

Poutanen, Mikko, Juntunen, Tapio, ja Lahtinen, Mikko, 2019a. Uusi toimitus, uusi julkaisutapa. Politiikka 61(1), 1-5.

Poutanen, Mikko, Juntunen, Tapio, ja Lahtinen, Mikko, 2019b. Muuttuva yliopisto. Politiikka 61(2), 99-102.

Raevaara, Tiina. 2020. ”Tieteen uudet ystävät." Suomen Kuvalehti 14.2.2020. https://suomenkuvalehti. fi/jutut/kotimaa/mielipide-kotimaa/kolumni-tiede-on-saanut-paljon-uusia-ystavia-todellisuudessamoni-paljastuu-sen-viholliseksi/. Viitattu 5.4.2020.

Ronkainen, Antti. 2019. "Rinteen hallituksen tietopohjaisuuden epätietoinen romahdus." Suomen Kuvalehti, 25.11.2019. https://suomenkuvalehti.fi/vallan-mahotonta/rinteen-hallituksen-tietopohjaisuuden-epatietoinen-romahdus/. Viitattu 20.3.2020.

Silvennoinen, Oula. 2017. "Suomi takaisin! Perussuomalaiset, populismi ja moderni fasismi." Politiikasta, 18.12.2017. https://politiikasta.fi/suomi-takaisin-perussuomalaiset-populismi-ja-modernifasismi/. Viitattu 22.3.2020.

Silvennoinen, Oula. 2019. "Kun historioitsija kohtaa vihaa." Politiikasta, 10.1.2019. https://politiikasta.fi/ kun-historioitsija-kohtaa-vihaa/. Viitattu 22.3.2020.

Tiedebarometri. 2019. Tieteen tiedotus. http://www.tieteentiedotus.fi/tiedebarometri.html. Viitattu 22.3.2020.

Valtioneuvosto. 2019. Osallistava ja osaava Suomi - sosiaalisesti, taloudellisesti ja ekologisesti kestävä yhteiskunta. 10.12.2019. Valtioneuvoston julkaisuja 2019:31. http://julkaisut.valtioneuvosto.fi/handle/10024/161931. Viitattu 20.3.2020.

Ylöstalo, Hanna. 2019. Hei Twitter! Eilisen menetelmäkeskustelun jälkeen arvelin, että on aihetta lyhyelle oppitunnille. Aiheena "Mitä laadullinen tutkimus on?" Tervetuloa, toivottavasti viihdyt! 1/ Twitter, 3.9.2019. https://twitter.com/ylostalohanna/status/1168758033339625478. Viitattu 20.3.2020.

Ylöstalo, Hanna. 2020. ”Asiantuntijavalta politiikassa." Politiikasta, 20.3.2020. https://politiikasta.fi/asiantuntijavalta-politiikassa/. Viitattu 22.3.2020. 